\title{
DETERMINANTS OF DISSEMINATION OF ENVIRONMENTAL INFORMATION: AN EMPIRICAL SURVEY
}

\author{
Grigoris GIANNARAKIS ${ }^{1}$, Eleni ZAFEIRIOU ${ }^{2}$, \\ Nikolaos SARIANNIDIS ${ }^{3}$, Kyriaki EFTHALITSIDOU ${ }^{4}$ \\ ${ }^{1}$ Department of Business Administration, Technological Education Institute of West Macedonia, \\ 51100, Grevena, Greece \\ ${ }^{2}$ Department of Agricultural Development, Democritus University of Thrace, \\ 193 Pantazidou str., Orestiada, Greece \\ 3,4 Department of Financial Applications, Technological Education Institute of West \\ Macedonia, Kila, 50100 Kozani, Greece \\ E-mails: ${ }^{1}$ ggianaris@gmail.com; ${ }^{2}$ ezafeir@agro.duth.gr (correspondingauthor); \\ 3sarn@hol.gr; ${ }^{4}$ efthalitsidou.kiki@hotmail.gr
}

Received 24 October 2015; accepted 26 May 2016

\begin{abstract}
The major objective of the present paper is to identify the factors that influence the dissemination of environmental information. In particular, analyst stock recommendation, country level risk, corporate value and environmental performance are surveyed as determinants of the environmental dissemination level. The survey was based on a sample of 92 multinational firms for the period 2009-2013, longer than that used in most past works. The methodology employed on our data is the panel data analysis with fixed effects. As proxies, for the dissemination level of environmental information, two different environmental disclosure indexes are used the Environmental Disclosure Score and Carbon Disclosure Leadership Index. According to our findings, the environmental performance in terms of Emission Reduction Initiatives and the country's risk premium affects in a positive way the dissemination of environmental disclosures while the results regarding the stock analyst recommendation are controversial. Another important finding is that the firm's value is validated as an insignificant factor for the dissemination level of environmental information. The aforementioned results provide the corporate managers with a tool to attract environmental friendly investors. The novelty on the present manuscript stands on the use of proxies for the environmental performance; namely the first one is based on outcome - objective while the second one refers to the corporate intention, elements that enrich the existing literature in the field of environmental behavior and dissemination of the environmental information of a firm.
\end{abstract}

Keywords: disclosure, Environmental Disclosure Score, Carbon Disclosure Leadership Index, panel data, fixed effects, Voluntary disclosure theory, Legitimacy theory.

JEL Classification: M140, M410, Q00. 


\section{Introduction}

Non-financial information has become vital for the socially responsible investors over the last decade. For instance, an increase in Socially Responsible Investment (SRI) market has been recorded in Europe within 11 and 38\% for the time period 2011-2013 (Eurosif 2014), in Australia and New Zealand has increased by almost 13\% reaching the amount of \$153 billion in assets in 2013 (Responsible Investment Association Australia 2014). In Canada, SRI represents one-fifth of assets in the financial industry (Social Investment Organization 2013).

This study uses the term of Corporate Social Responsibility (CSR) in order to describe the non-financial information provided on the environmental disclosure as a part of CSR disclosure (Said et al. 2013; Qiu et al. 2016).

The major novelty of the study stands on the comparison of the effect of determinants on two different environmental disclosure indexes. The first environmental disclosure index incorporates criteria taking into account the board aspect of environment while the second one focuses only on carbon emission information. Despite the increased interest on determinants of the dissemination level of environmental information (i.e. Patten 2002; Hughes et al. 2001; Al-Tuwaijri et al. 2004; Clarkson et al. 2008; Luo, Tang 2014; Liao et al. 2015; Qiu et al. 2016; Rankin et al. 2011), there is still a number of novelty determinants that have not been incorporated in relation to the extent of environmental disclosure. Based on Matten and Moon (2008) approach, the country risk premium is selected for the first time in order to ascertain whether the additional market risk may affect the environmental disclosure initiatives. In addition, even if the determinant of environmental performance is well investigated on the environmental disclosure level, the study uses two proxies based on different approaches for the extent of environmental disclosure. The first proxy is based on terms of output (Patten 2002; Clarkson et al. 2008; Luo, Tang 2014) Environmental Disclosure Score (EDS) as provided by Bloomberg database while the second one is based on terms of commitment to the environment without feeling the pressure for the environmental outcome entitled Carbon Disclosure Leadership Index $(C D L I)$ and calculated by Carbon Disclosure Project (Graafland et al. 2004). As CSR initiatives and score has generated a growing interest by financial investment analysts (Luo et al. 2015), it is intended to point out how the dissemination level of environmental information changes by analyst stock recommendation. Moreover, studies that investigate the effect of firm value on the extent of non-financial disclosure found controversial results (Drobetz et al. 2014; De Villiers, Va Staden 2011, Chen et al. 2014), for instance, Tobin's Q variable is reconsidered in the proposed model to ascertain the effect on the extent of environmental disclosure.

Secondly, a five-year period is used contrary to the majority of prior studies focused on one year corporate data. Finally, the study employs data on the world's largest multinational firms involving different countries and geographical regions as represented by the Dow Jones Titans Indices (incorporating different political regimes, socio-economic conditions, labour relations, monetary systems and other specific conditions).

The rest of the paper is organized as follows; in the first section a brief presentation of the existing literature and hypotheses development are presented while in the next 
Section 2 the data and the methodology employed are described in subtle. Section 3 illustrates the results of the study along with the discussion of the results presented in Section 4. The last section concludes.

\section{Theory and hypotheses development}

Two different strands of literature can be identified on the issue of environmental disclosure of firm. The first one involves studies that refer to environmental disclosures (i.e Qiu et al. 2016; Monteiro, Aibar-Guzmán 2010; Al-Tuwaijri et al. 2004; Tagesson et al. 2009; Eleftheriadis, Anagnostopoulou 2015) and the second one is related to the carbon emission disclosures by incorporating the CDLI (Luo, Tang 2014; Liao et al. 2015; Rankin et al. 2011; Prado-Lorenzo, Garcia-Sanchez 2010; Freedman, Jaggi 2005). A few notable remarks can be underlined. Firstly, studies focused on a specific year without referring to a longer time period. Apart from Prado-Lorenzo and GarciaSanchez (2010), the sample of prior studies include listed firms, probably, because it is more possible to integrate CSR initiatives of large in size firms in their operations than small-medium size firms (Freedman, Jaggi 2005). Regarding the development of environmental disclosure index, the disclosure items are based on the authors' perception or based on a few criteria regarding GRI leading to a simple and brief approach for the extent of environmental disclosure. The majority of the prior studies focused on equal weight disclosure items for the composition of environmental index. In addition, except for Rankin et al. (2011) and Al-Tuwaijri et al. (2004), the studies used a dichotomous variable, 1 or 0 , depending on whether the item was disclosed or not. Furthermore, the present study uses an approach that is consistent to a number of studies that develop a CSR disclosure index (i.e. Siregar, Bachtiar 2010; Tagesson et al. 2009).

In total, four explanatory variables significant to the investors' decision, namely country risk premium, analyst stock recommendation, corporate value and environmental performance are employed in order to interpret the dissemination level of environmental information, the selection of which was based on the existing literature presented in subtle in the following paragraphs.

\subsection{Country risk}

Primarily, country risk concerns the ability of a country to serve its financial obligations (Cosset, Roy 1991). The country risk premium is used as a proxy for the political stability (Oetzel et al. 2011; Glova 2014). Rodriguez et al. (2014) based on Matten and Moon (2008), pointed out that the country risk is an important variable that guides the international investors. Four propositions were developed in relation to explicit and implicit Corporate Responsibility (CR). The first concerns a very high level of country risk in which firms are not engaged in explicit CR and develop limited implicit CR. The second one concerns countries with high risk where firms decrease their investments in explicit $\mathrm{CR}$ and engage in limited implicit CR, while under moderate level of country risk firms tend to invest a very high rate of explicit CR and adhere to increase implicit CR. Finally, firms that operate in low and very low level country risk decrease their investment in explicit CR because governments and institutions are able to satisfy the social expectations. 
The firms that operate in high country risk conditions tend to eliminate their CSR initiatives because they want to retain their ability to withdraw their investments in unstable situations. Therefore, investments in CSR initiatives, such as disclosures can be counterproductive, as the costs of CR investments would outweigh the benefits. The following hypothesis is established.

$\mathbf{H}_{\mathbf{1}}$ : High levels of country risk premium affect negatively the dissemination level of environmental information.

\subsection{Analyst stock recommendation}

Stock analyst are certified experts that obtain and process corporate information regarding firms that is not accessible to individual investors and other stakeholders so as to assess better CSR performance (Luo et al. 2015; Ivkovic, Jegadeesh 2004). According to Ivkovic and Jegadeesh (2004), stock analysts are responsible for the manipulation of corporate information in order to disseminate it both to investor and institutions. The stock analyst recommendation has begun to take into account the CSR since SRI have triggered the interest of investors (Eurosif 2014, Responsible Investment Association Australia 2014, Social Investment Organization 2013). Stock analysts pay attention to CSR information for their recommendations to investors (Luo et al. 2015). Furthermore, firms with higher levels of CSR attract the interest of analysts achieving lower absolute forecast errors and dispersion (Dhaliwal et al. 2011). The following hypothesis is established.

$\mathbf{H}_{\mathbf{2}}$ : Lower stock rating by analysts increases the dissemination level of environmental information.

\subsection{Firm value}

Tobin's Q is used widely in prior researches as a proxy for corporate valuation (Al-Akra, Ali 2012; Garay et al. 2013; Chen et al. 2014). Prior researches are limited regarding the effect of corporate value on environmental disclosure.

Drobetz et al. (2014) found that there is a positive relationship between CSR disclosure and Tobin's q, implying that the portfolio performance can be improved by including firms which enhance CSR disclosure. Chen et al. (2014) focused on the Chinese business environment found that a negative relation between firm value and non-financial disclosure for firms taking into account guanxi (interpersonal ties, relationships or connections) in the new investment projects. De Villiers and Van Staden (2011) found that Tobin's q affects negatively the information level of environmental information on annual report while Clarkson et al. (2008) revealed an insignificant effect of firm value on environmental disclosure. In this study, the following hypothesis is established.

$\mathbf{H}_{3}$ : Higher level of Tobin's decreases the dissemination level of environmental information.

\subsection{Environmental performance}

The voluntary disclosure theory predicts that higher environmental performance has a positive effect on the environmental disclosure so as to differentiate themselves by the inferior type companies (Verrecchia 1983; Li et al. 1997). Whilst, the legitimacy theory 
predicts that lower environmental performance has a negative effect on environmental disclosure in order to face the social pressure (Patten 2002).

Regarding empirical studies, on the one hand, Luo and Tang (2014) found a positive relationship between environmental disclosure and performance consistent to signaling theory consistent with Clarkson et al. (2008). Good environmental performers are more honest in disclosing that performance and the environmental disclosure can be used as proactive communication tool to inform investors (Al-Tuwaijri et al. 2004).

On the other hand, Patten (2002) revealed a significant negative relation between performance and disclosure consistent with Ingram and Frazier (1980). Furthermore, firms from non-environmentally sensitive industries tend to incorporate more information for higher levels of toxic release levels than firms do from environmentally sensitive industries. Finally, Hughes et al. (2001) indicated that the extent of environmental disclosures is not related to the actual environmental performance consistent to Wiseman (1982). However, Meng et al. (2014) found that comparing the poor and good performers, the good ones tend to disseminate more environmental information.

Based on Graafland et al. (2004), when the intention of a moral action is good, the outcome of that action does not matter; thus, the emission reduction initiatives are proposed as a proxy for the environmental performance. In this index, the firms show the commitment to the environment without feeling the pressure for their outcome. Another index as a proxy for the environmental performance is in terms of outcome, namely GHGE. In this study, the following hypotheses are established:

$\mathbf{H}_{\mathbf{4 a}}$ : Higher levels of environmental performance affect positively the environmental disclosure level as implied by voluntary disclosure theory.

$\mathbf{H}_{\mathbf{4 b}}$ : Lower levels of environmental performance affect positively the environmental disclosure level as implied by legitimacy theory.

\section{Data and methodology}

\subsection{Data}

The data employed in this study involve firms listed on Dow Jones Country Titans Indexes located in different countries and geographical regions under different institutional regimes and socio - economic conditions for the period 2009-2013. Each Country Titans Index includes selective firms from the respective country index with the objective to optimize the factors of greatest importance in an investable index: liquidity, turnover rate, transaction costs and tracking error against broad-market benchmarks. In total, the Dow Jones Country Titans Indexes 2011 from 23 countries consist of 720 firms (Dow Jones Country Titans Indexes, 2011). The Dow Jones Country Titans Indexes 2011 was selected for the purpose of this study since large-sized firms are expected to develop CSR disclosures initiatives (Reverte 2009).

\subsection{Dependent and independent variables}

As dependent variables, two environmental indexes are employed as proxies for the dissemination level of environmental information. The first one concerns $E D S$ as cal- 
culated by Bloomberg, while the second proxy is the CDLI as calculated by Carbon Disclosure Project (CDP).

To be more specific, Bloomberg has created a CSR disclosure score based on three distinguished disclosure pillars called Environmental Social Governance Disclosure Score. In particular, the $E D S$ is based on environmental disclosure items adjusted by industry and weighted by importance. Thus, the score is tailored to industries' considerations incorporating specific industry criteria ranging from 0 to 100 as percentage for comparison purposes across firms. Furthermore, "hard" disclosure items are considered to the development of EDS incorporating information, such as Carbon/GHG emissions and energy/water consumption covering approximately, $80 \%$ of the total disclosure items. The rest $20 \%$ concerns "soft" disclosure items, such as energy efficiency policy. A short description of the disclosure data items are presented by Qiu et al. (2016). Bloomberg's methodology takes into account a wider source of information, such as CSR reports, annual reports, company's web sites and the Bloomberg survey. Transparency limitations within methodological steps are taken into consideration in order the calculation of the disclosure score to be explained as they are easily imitated by other assessment organizations losing its competitiveness edge (Delmas, Blass 2010). However, a number of studies can be mentioned that employed Bloomberg ESG data (e.g. Wang, Sarkis 2013; Eccles et al. 2011; Ioannou, Serafeim 2015).

The role of carbon disclosure score and its determinants has not been a subject of extended survey; however, in the course of the last five years, the CDLI score has become subject of the research (i.e. Andrew, Cortese 2013; Luo, Tang 2014; Prado-Lorenzo, Garcia-Sanchez 2010; Liao et al. 2015).

This proxy captures the dissemination level of carbon disclosure score. The $C D L I$ is composed of each firm based on the total attainable score divided by the total available score and then normalized to a 100-point scale. Most of the answers to CDLI questionnaire are binary where 1 or 0 depends on whether the item was disclosed or not, while other answers are qualitative or narrative answers. Some of the issues that $C D L I$ covers are: the extent to which a company measures its carbon emissions, the comprehensiveness of the information that provides on climate-related actions, the depth of information given on the issues climate change presents to the business and whether a company uses a third party for external verification of its data in order to promote greater confidence and usage of the data (CDP 2013a). Also, firms should respond publicly and submit via CDP's Online Response System and achieve a score within the top 10\% in order to enter in CDLI (CDP 2013b).

Regarding the control variables, the company's size has been widely used in prior studies in order to enhance the relationship between the explanatory determinants and CSR or environmental disclosure (i.e. Clarkson et al. 2008; Said et al. 2009; Tagesson et al. 2009). Table 1 summarizes the definition and the measurement of variables employed in our survey as retrieved by Bloomberg database: 
Table 1. Description of variables

\begin{tabular}{ll}
\hline \multicolumn{1}{c}{ Variables } & \multicolumn{1}{c}{ Description } \\
\hline $\begin{array}{l}\text { Country Risk } \\
\text { Premium }\end{array}$ & $\begin{array}{l}\text { Expected market return value is based on the total accumulated investment risk for } \\
\text { the country or region selected in Country Risk. The risk premium is only computed } \\
\text { for countries or regions which have a known risk free rate. }\end{array}$ \\
\hline $\begin{array}{l}\text { Best Analyst } \\
\text { Rating }\end{array}$ & $\begin{array}{l}\text { Bloomberg Estimates current analyst rating. A ratings scale between '1' and '5' is } \\
\text { used. A return of '5' is the strongest ranking (buy or similar), whereas a return of } \\
\text { '1' is the weakest (sell or similar). }\end{array}$ \\
\hline Tobin's q & $\begin{array}{l}\text { (Market Capitalization + Total Liabilities + Preferred Equity + Minority Interest) / } \\
\text { Total Assets. }\end{array}$ \\
\hline $\begin{array}{l}\text { Greenhouse } \\
\text { Gas } \\
\text { Emissions }\end{array}$ & $\begin{array}{l}\text { Total Greenhouse Gas (GHG) Emissions of the company, in thousands of metric } \\
\text { tons. Greenhouse Gases are defined as those gases which contribute to the trapping } \\
\text { of heat in the Earth's atmosphere and they include Carbon Dioxide (CO2), } \\
\text { Methane, and Nitrous Oxide divided to Sales. }\end{array}$ \\
\hline $\begin{array}{l}\text { Emission } \\
\text { Reductions } \\
\text { Initiatives }\end{array}$ & $\begin{array}{l}\text { Indicates whether the company has implemented any initiatives to reduce its } \\
\text { environmental emissions to air ('1' - Yes or '0' - No). }\end{array}$ \\
\hline Sales & \begin{tabular}{l} 
Total of operating revenues. \\
\hline
\end{tabular}
\end{tabular}

\subsection{Model development}

Different regression analysis models have been developed in the field of CSR and environmental disclosure and its explanatory variables, such as multiple linear regression (i.e. Siregar, Bachtiar 2010; Reverte 2009; Prado-Lorenzo et al. 2009), both univariate and multivariate regression models (Liao et al. 2015), multivariate regression analysis through stepwise method (Monteiro, Aibar-Guzmán 2010), unranked and ranked regression (Jennifer Ho, Taylor 2007) and hierarchical regression analysis (Said et al. 2009).

In our case, a fixed effect model was employed in this study because of the advantages over traditional regression approaches. For instance, it removes the effects of timeinvariant causes, independently on whether those causes are measured or not; thus, it can alleviate omitted-variable bias in a less-than-fully-specified model (Firebaugh et al. 2013). With the assistance of STATA software, the four models to be estimated are the following:

$$
\begin{array}{ll}
\mathrm{CDLI}=\mathrm{a}_{0}+\mathrm{b}_{1} * \mathrm{CRP}+\mathrm{b}_{2} * \mathrm{TQ}+\mathrm{b}_{3} * \mathrm{BAR}+\mathrm{b}_{4} * \mathrm{CHGES}+\mathrm{b}_{5} * \mathrm{CS}+\mathrm{u} & (\text { Model } 1), \\
\mathrm{EDS}=\mathrm{a}_{0}+\mathrm{b} 1 * \mathrm{CRP}+\mathrm{b} 2 * \mathrm{TQ}+\mathrm{b} 3 * \mathrm{BAR}+\mathrm{b} 4 * \mathrm{CHGES}+\mathrm{b} 5 * \mathrm{CS}+\mathrm{u} & (\text { Model }), \\
\mathrm{CDLI}=\mathrm{a}_{0}+\mathrm{b}_{1} * \mathrm{CRP}+\mathrm{b}_{2} * \mathrm{TQ}+\mathrm{b}_{3} * \mathrm{BAR}+\mathrm{b}_{4} * \mathrm{ERI}+\mathrm{b}_{5} * \mathrm{CS}+\mathrm{u} & (\text { Model 3), } \\
\mathrm{EDS}=\mathrm{a}_{0}+\mathrm{b}_{1} * \mathrm{CRP}+\mathrm{b}_{2} * \mathrm{TQ}+\mathrm{b}_{3} * \mathrm{BAR}+\mathrm{b}_{4} * \mathrm{ERI}+\mathrm{b}_{5} * \mathrm{CS}+\mathrm{u} & (\text { Model 4), }
\end{array}
$$

where: $E D S=$ Environmental Disclosure Score; $C D L I=$ Carbon Disclosure Leadership Index; $C R P=$ Country Risk Premium; $T Q=$ Tobin's q; $B A R=$ Best Analyst Rating; GHGES = Greenhouse Gas Emissions divided to Sales; $E R I=$ Emission Reduction Initiatives; $C S=$ Company's size; $a=$ intercept; $u=$ error term. 
A Shapiro-Wilk test was conducted for detecting the normality of observations. Furthermore, a Wooldridge's test autocorrelation test as well as the Breusch-Pagan heteroscedasticity test were implemented on the residuals, while with the assistance of a correlation matrix we detected multicollinearity between independent variables.

\section{Results}

\subsection{Descriptive statistics and correlation matrix}

Our sample is consisted of 92 firms (corresponding to $12.7 \%$ of the total). Table 2 presents the descriptive statistics of both dependent and independent variables. For instance, even if firms are obliged to provide environmental information, the mean score of $C D L I$ can be considered very high reaching 81.67 , whilst the $E D S$ is, approximately, half the $C D L I$ score. It is ascertained that the senior management recognize the business issues regarding the $C D L I$ criteria. Furthermore, the majority of the firms implement $E R I$ with low standard deviation level, while the mean score of Tobin's q is 1.52 suggesting that the firms including in the sample are overestimated. Finally, no multicollinearity is confirmed and thus there is no limitation to the implementation of the methodology to our data because the correlations between independent variables do not exceed the value 0.8 or 0.9 that could cause harmful consequences to the proposed models (Gujarati 1995).

Table 2. Descriptive statistics

\begin{tabular}{ccccc}
\hline Variables & Mean & sd & Min & Max \\
\hline EDS & 46.43 & 12.07 & 14.29 & 80.17 \\
\hline CDPLI & 81.67 & 13.76 & 30 & 100 \\
\hline CRP & 9.15 & 2.27 & 3.60 & 16.94 \\
\hline BAR & 3.72 & 0.56 & 1.77 & 5 \\
\hline GHGE & $9,484.669$ & $23,250.46$ & 5,182 & 157,783 \\
\hline ERI & 0.98 & 0.13 & 0 & 1 \\
\hline TQ & 1.52 & 0.88 & 0.78 & 7.32 \\
\hline CS & $3,130,225.7$ & $20,558,995$ & $1,212,933$ & $228,692,667$ \\
\hline
\end{tabular}

\subsection{Fixed effects results}

The implementation of Shapiro-Wilk test revealed that the data are not normally distributed, thus, variables are transformed by using the logarithm procedure (Field 2013). The Huber-White robust clustered standard errors approach was employed in order to adjust any potential heteroskedasticity and serial correlation (Wooldridge 2002; Stock, Watson 2007; Neter et al. 1983). Table 3 reveals the result of the regression analysis used to test $\mathrm{H}_{1}-\mathrm{H}_{4}$.

Regarding the first Model, the R squared equals to 0.52 indicating that the explanatory variables explain $52 \%$, approximately, of the variance in $C D L I$ with $\mathrm{F}$ values equal to $8.18(\mathrm{p}<0.01)$. Country risk premium is found significantly positive at the $5 \%$ on $C D L I$ 
whilst analyst stock recommendation is negatively significant at the $1 \%$. Furthermore, the company's size is statistically significant at $1 \%$ level positive to $C D L I$.

In Model 2, the explanatory power of predetermined variables is greater than in Model 1 with adjusted R-square 0.74 and $F$ value equals to $2.79(\mathrm{p}<0.05)$. The variables $C R P$, and $B A R$ are statistically significant and positive to $E D S$ at the $10 \%$ and $5 \%$ level, respectively. The rest of the recommended variables are not statistically significant to EDS.

In Model 3, the volatility of $C D L I$ can be explained at $52.83 \%$ with $\mathrm{F}$ value to be equal to $12.45(\mathrm{p}<0.01)$. In addition, $C R P$ and $E R I$ are statistically significant and positive to $C D L I$ at $10 \%$ and $1 \%$ level, respectively, while $B A R$ is negatively significant at $1 \%$ level. Furthermore, the company's size is statistically significant at 5\% level positive to $C D L I$.

In the last Model, the $\mathrm{R}$ square is 0.76 indicating that the independent variables explain $76 \%$ of the volatility in $C D L I$ with $6.04(\mathrm{p}<0.01) . B A R$ is statistically significant and positive to $E D S$ consistent to Model 3 and $E R I$ is significantly positive at the $1 \%$ to $E D S$. Moreover, both $C R P$ and $T Q$ are statistically significant at $10 \%$ level to $E D S$ :

Table 3. Models' estimation results

\begin{tabular}{ccccc}
\hline & $\begin{array}{c}\text { Model 1 } \\
\text { CDLI }\end{array}$ & $\begin{array}{c}\text { Model 2 } \\
\text { EDS }\end{array}$ & $\begin{array}{c}\text { Model 3 } \\
\text { CDLI }\end{array}$ & $\begin{array}{c}\text { Model 4 } \\
\text { EDS }\end{array}$ \\
\hline Variables & Coefficient & Coefficient & Coefficient & Coefficient \\
\hline CRP & $0.0650509^{* *}$ & $0.0719128^{* * *}$ & $0.0596232^{* * *}$ & $0.0728656^{* *}$ \\
\hline TQ & -0.0491116 & 0.0463715 & -0.0765351 & $-0.1041359^{* * *}$ \\
\hline BAR & $-0.2655963^{*}$ & $0.1778608^{* *}$ & $-0.2697151^{*}$ & $0.1369011^{* * *}$ \\
\hline CHGES & 0.0166827 & -0.0715131 & & \\
\hline ERI & & & $0.1561265^{*}$ & $0.3856462^{*}$ \\
\hline CS & $0.2758163^{*}$ & -0.05555 & $0.261893^{*}$ & -0.0014346 \\
\hline C & $1.771945^{*}$ & $3.76168^{*}$ & $1.73226^{* *}$ & $3.134842^{*}$ \\
\hline Adj R square & 0.52 & 0.74 & 0.5283 & 0.76 \\
\hline F & $8.18^{*}$ & $2.79 * *$ & $12.45^{*}$ & $6.04^{*}$ \\
\hline
\end{tabular}

Notes: ***Significant at the 0.10 level (2-tailed), **Significant at the 0.05 level (2-tailed), *Significant at the 0.01 level (2-tailed), Adj R-squared was calculated by areg command.

\section{Discussion of results}

As far as the country risk premium concerns, the results indicate that firms located in countries with high risk premium increase the information level of environmental disclosure rejecting $\mathrm{H}_{1}$. Thus, when the country risk is high firms tend to take on more environmental disclosure initiatives beyond the legal requirements a result that is inconsistent to Matten and Moon (2008). A potential explanation is that firms need to signal a sign for the true commitment to social expectations regarding the environment and 
their commitment to operation for a long period of time. The results show that firms are not restricted to nominal initiatives but they develop a communication channel to society via environmental disclosures. On the contrary, when the country risk is lower, government and institutions satisfy the social expectations, while firms tend to limit the disclosure initiatives as they affect negatively the firms' profit and the shareholder's wealth (Rodriguez et al. 2014).

Another finding of this study is related to the controversial impact of analyst stock recommendations on the dependent variable. To be more specific, based on $C D L I$, when the analyst rating is low, firms tend to increase the level of carbon emission information so as to allocate the disclosure cost in other core business operations (accepting $\mathrm{H}_{2}$ ). It is implied that $C D L I$ is considered as an information based mechanism for investors and other stakeholders in order to assess the environmental concerns of companies (Luo et al. 2015). In particular, lower rating by stock analysts lead companies to increase the extent of carbon emission information level in order to reverse the perception of investors. Consequently, socially responsible investors have the opportunity to assess their investments and evaluate their current portfolios in environmental terms It is implied that $C D L I$ is considered as an information based mechanism for investors and other stakeholders in order to assess the environmental concerns of companies (Luo et al. 2015). In particular, lower rating by stock analysts lead companies to increase the extent of carbon emission information level in order to reverse the perception of investors. Consequently, socially responsible investors have the opportunity to assess their investments and evaluate their current portfolios in environmental terms by themselves (EY 2014). Furthermore, investors by analyzing the carbon emission information determine by their own the value, the future prospects of businesses and costs of pollution control (Bewley, Li 2000). Finally, the increased information level does not only aim to inform and change investors' perception but the same stock analyst as well because CSR initiatives are considered for their rating (Luo et al. 2015). However, based on EDS, when the analyst stock rating is higher, firms tend to incorporate more environmental information in their disclosure, probably, to take advantage from their competitors by pointing out their environmental concerns intensifying the increased rating by analysts (rejecting $\mathrm{H}_{2}$ ). The effect of stock analyst recommendation on extent of environmental disclosure should be made by caution. The broad concept of environment that concerned by EDS procedure play a crucial role for the contradictory results.

Furthermore, investors by analyzing the carbon emission information determine by their own the value, the future prospects of businesses and costs of pollution control (Bewley, Li 2000). Finally, the increased information level does not only aim to inform and change investors' perception but the same stock analyst as well because CSR initiatives are considered for their rating (Luo et al. 2015). However, based on EDS, when the analyst stock rating is higher, firms tend to incorporate more environmental information in their disclosure, probably, to take advantage from their competitors by pointing out their environmental concerns intensifying the increased rating by analysts (rejecting $\mathrm{H}_{2}$ ). The effect of stock analyst recommendation on extent of environmental disclosure should be made by caution. The broad concept of environment that concerned by EDS procedure play a crucial role for the contradictory results. 
Regarding the effect of Tobin's q, it is found in almost all cases that the firm's value does not affect the dissemination level of environmental information a result that is consistent to Clarkson et al. (2008) and non in line with this of De Villiers and Van Staden (2011) and Chen et al. (2014). However, it should be pointed out that in Model 4 , Tobin's q has a negative impact on the disclosure level (accepting $\mathrm{H}_{3}$ ) - a result that is consistent to De Villiers and Van Staden (2011) and Chen et al. (2014) where firms eliminate the disclosure level as it can outweigh the discourse's benefit and, probably, they may not have any potential private information to provide.

Furthermore, the results show firms that have taken initiatives to reduce its environmental gas emissions seem to incorporate more information to their disclosures in order to distinguish themselves for investors and other stakeholders (Verrecchia 1983; Dye 1985; Li et al. 1997). This result is consistent to Luo and Tang (2014), Clarkson et al. (2008) and Al-Tuwaijri et al. (2004) accepting $\mathrm{H}_{4 \mathrm{a}}$. The result is inconsistent to legitimacy theory which predicts an inverse relationship between environmental performance and disclosure sending a misleading signal to stakeholders (Hughes et al. 2001; Wiseman 1982; Patten 2002). Thus, this study show that good environmental performers in terms of intentions are expected to be more straightforward in their environmental disclosure. This, in turn, increases the confidence of investors for environmental disclosures as a measure of corporate environmental performance. Corporate managers believe that the good environmental performance is a positive signal for market participants a fact that is consistent to discretionary disclosure theory (Al-Tuwaijri et al. 2004). In addition, conveying superior environmental performance to disclosure, companies can enhance their image and reputation (Guthrie, Parker 1990) and develop brand competitive advantage (Waddock, Graves 1997). Finally, it can be inferred that companies that select to present corporate information via third party disclosure assessment such as $E D S$ and $C D L I$ are not allowed to manipulate the outcome, implying more reliable information for all stakeholders (Luo, Tang 2014).

Furthermore, the firm's size as a control variable seems to affect the dissemination level of information in terms of CDLI consistent to Luo and Tang (2014), Andrikopoulos and Kriklani (2013) and Clarkson et al. (2008). A number of potential explanations have been phrased in the existing literature, including avoidance of the social scrutiny or maintaining company's legitimacy in the eyes of society (Branco, Rodrigues 2008; Meng et al. 2014).

The results of the study entail both managerial and academic implications. First of all, both corporate policy makers and reporting regulators should tailor the specific determinants to future reporting guidelines leading to more effective communication between insiders and outsiders of company. In addition, based on the intention of moral action where the outcome does not matter, companies with superior environmental performance are more forthcoming in truly discretionary disclosure channels increasing the dissemination level of information, as supported by economics based voluntary disclosure theory. Thus, if a company increases the dissemination level of environmental information vulnerably, it is likely to have superior environmental record in terms of commitment such as ERI. Furthermore, companies that intend to expand their business 
operations in other countries should consider the country risk premium in the communication approach to stakeholders; thus the extent of environmental and carbon emission disclosure is changed according to market risk level.

\section{Conclusions}

The present study makes an effort to survey a firm's environmental dissemination level as a function of variables that affect the investors' decision making; namely, the analyst stock recommendation, the country level risk, the corporate value and the environmental performance. As proxies for the firm's environmental performance is used the GHGE in terms of outcome and ERI in terms of corporate intention.

The country risk premium in the proposed model is used to capture the differences in business environment since Dow Jones Titans Indices include firms settled in different countries and geographical regions confronting different macroeconomic conditions. For these cases and according to our findings, extensive dissemination level of environmental information can be developed by corporate managers as an effective policy tool to get over the consequences of political instability. Moreover, there was not a confirmation for the impact of a firm's value on the dissemination level of environmental information, a result that is inconsistent to the initial hypothesis development. Furthermore, the results are controversial regarding the analyst stock recommendation. To be more specific, based on $C D L I$, when the analyst recommendation is lower for a specific firm, managers tend to provide less carbon emission information, whilst based on $E D S$, when the analyst recommendation is higher for a specific firm, managers disseminate more environmental information, in order to take an advantage from their competitors. Finally, firms with better environmental performance in terms of corporate intention by incorporating $E R I$, intend to further improve the information level distinguishing themselves from firms with inferior performance, according to voluntary disclosure theory.

Despite limitations, this study contributes to the existing literature in different ways. First of all, it extends previous works as it incorporates and compares the impact of determinants on two different environmental disclosure indexes. The first index concerns the $E D S$ calculated by Bloomberg based on criteria that take into account the board attitude towards the environment while the second one considers only the carbon emission issue as calculated by CDP. In addition, the study intends to revisit the relationship between two environmental performance proxies and disclosure. The selection of the proxies is based on different approaches; the first is using the outcome-objective criterion, while the second one is intention oriented for the firms without taking into consideration the results; therefore carbon emissions data and ERI are adopted for each case, respectively. As a last but certainly not least is the fact that the stock analyst recommendation and country risk are used to interpret the environmental disclosure for the first time while the impact of firm value on environmental disclosure is controversial and could be a subject of future survey. 


\section{References}

Al-Akra, M.; Ali, M. J. 2012. The value relevance of corporate voluntary disclosure in the Middle-East: the case of Jordan, Journal of Accounting and Public Policy 31(5): 533-549. http://dx.doi:10.1016/j.jaccpubpol.2011.10.007

Al-Tuwaijri, S. A.; Christensen, T. E.; Hughes II, K. E. 2004. The relations among environmental disclosure, environmental performance, and economic performance: a simultaneous equations approach, Accounting, Organizations and Society 29(5-6): 447-471.

http://dx.doi:10.1016/S0361-3682(03)00032-1

Andrew, J.; Cortese, C. 2013. Free market environmentalism and the neoliberal project: the case of the Climate Disclosure Standards Board, Critical Perspectives on Accounting 26(4): 397-409. http://dx.doi:10.1016/j.cpa.2013.05.010

Andrikopoulos, A.; Kriklani, N. 2013. Environmental disclosure and financial characteristics of the firm: the case of Denmark, Corporate Social Responsibility and Environmental Management 20(1): 55-64. http://dx.doi:10.1002/csr.1281

Bewley, K.; Li, Y. 2000. Disclosure of environmental information by Canadian manufacturing companies: a voluntary disclosure perspective, Advances in Environmental Accounting and Management 1:201-226. http://dx.doi: 10.1016/S1479-3598(00)01011-6

Branco, M. C.; Rodrigues, L. L. 2008. Social responsibility disclosure: a study of proxies for the public visibility of Portuguese banks, The British Accounting Review 40(2): 161-181.

http://dx.doi:10.1016/j.bar.2008.02.004

Carbon Disclosure Project. 2013a. Climate Disclosure Leadership Index 2013 [online], [cited 26 January, 2015]. CDP Driving Sustainable Economies. Available from Internet: https://www.cdp. net/en-us/results/pages/cdp-2013-disclosure-scores.aspx

Carbon Disclosure Project. 2013b. Sector insights: what is driving climate change action in the world's largest firms? Global 500 Climate Change Report 2013 [online], [cited 26 January, 2015]. CDP Driving Sustainable Economies. Available from Internet: https://www.cdp.net/cdpresults/cdp-global-500-climate-change-report-2013.pdf

Chen, J. J.; Cheng, X.; Gong, S. X.; Tan, Y. 2014. Do higher value firms voluntarily disclose more information? Evidence from China, The British Accounting Review 46(1): 18-32.

Clarkson, P. M.; Li, Y.; Richardson, G. D.; Vasvari, F. P. 2008. Revisiting the relation between environmental performance and environmental disclosure: an empirical analysis, Accounting, Organizations and Society 33(4-5): 303-327.http://dx.doi:10.1016/j.aos.2007.05.003

Cosset, J. C.; Roy, J. 1991. The determinants of country risk ratings, Journal of International Business Studies 22(1): 135-142.

De Villiers, C. D.; Van Staden, C. J. 2011. Where firms choose to disclose voluntary environmental information, Journal of Accounting and Public Policy 30(6): 504-525.

http://dx.doi:10.1016/j.jaccpubpol.2011.03.005

Delmas, M.; Blass, V. D. 2010. Measuring corporate environmental performance: the trade-offs of sustainability ratings, Business Strategy and the Environment 19(4): 245-260.

http://dx.doi:10.1002/bse.676

Dhaliwal, D. S.; Li, O. Z.; Tsang, A.; Yang, Y. G. 2011. Voluntary nonfinancial disclosure and the cost of equity capital: the initiation of corporate social responsibility reporting, The Accounting Review 86(1): 59-100. http://dx.doi.org/10.2308/accr.00000005

Dow Jones Country Titans Indexes ${ }^{\mathrm{SM}}$. 2011. Guide to the Dow Jones Country Titans Indexes ${ }^{S M}$ [online], [cited 20 January, 2015]. Dow Jones Indexes A CME Group Company. Available from Internet: http://www.djindexes.com/mdsidx/downloads/rulebooks/Dow_Jones_Country_Titans_ Indexes_Rulebook.pdf 
Drobetz, W.; Merikas, A.; Merika, A.; Tsionas, M. G. 2014. Corporate social responsibility disclosure: the case of international shipping, Transportation Research Part E: Logistics and Transportation Review 71: 18-44. http://dx.doi:10.1016/j.tre.2014.08.006

Dye, R. A. 1985. Disclosure of non-proprietary information, Journal of Accounting Research 23(1): 123-145.

Eccles, R. G.; Serafeim, G.; Krzus, M. P. 2011. Market interest in nonfinancial information, Journal of Applied Corporate Finance 23(4): 113-127.

http://dx.doi: 10.1111/j.1745-6622.2011.00357.x

Eleftheriadis, I. M.; Anagnostopoulou, E. G. 2015. Relationship between Corporate Climate change disclosures and firm factors, Business Strategy and the Environment 24(8): 780-789. http://dx.doi: 10.1002/bse.1845

Eurosif. 2014. European SRI Study [online], [cited 15 December, 2014]. Eurosif A.I.S.B.L. Available from Internet: http://www.eurosif.org/publication/view/european-sri-study-2014

Field, A. P. 2013. Discovering statistics using SPSS: and sex and drugs and rock ' $n$ ' roll (4th edition). London: Sage.

Firebaugh, G.; Warner, C.; Massoglia, M. 2013. Fixed effects, random effects, and hybrid models for causal analysis, in Handbook of causal analysis for social research: Part of the series Handbooks of Sociology and Social Research. 113-132.

Freedman, M.; Jaggi, B. 2005. Global warming, commitment to the Kyoto protocol, and accounting disclosures by the largest global public firms from polluting industries, International Journal of Accounting 40(3): 215-232. http://dx.doi:10.1016/j.intacc.2005.06.004

Garay, U.; González, M.; Guzmán, A.; Trujillo, M. A. 2013. Internet-based corporate disclosure and market value: evidence from Latin America, Emerging Markets Review 17: 150-168.

http://dx.doi:10.1016/j.ememar.2013.09.002

Glova, J. 2014. Country risk in the CESEE countries: a fundamental beta approach, Procedia Economics and Finance 15: 100-107. http://dx.doi:10.1016/S2212-5671(14)00453-5

Graafland, J. J.; Eijffinger, S. C. W.; Smidjohan, H. 2004. Benchmarking of corporate social responsibility: methodological problems and robustness, Journal of Business Ethics 53(1-2): $137-152$.

Gujarati, D. N. 1995. Basic econometrics. New York: McGraw-Hill.

Guthrie, J. E.; Parker, L. D. 1990. Corporate social disclosure practice: a comparative international analysis, Advances in Public Interest Accounting 3: 159-176.

Hughes, S. B.; Anderson, A.; Golden, S. 2001. Corporate environmental disclosures: are they useful in determining environmental performance?, Journal of Accounting and Public Policy 20(3): 217-240. http://dx.doi:10.1016/S0278-4254(01)00031-X

Ingram, R. W.; Frazier, K. B. 1980. Environmental performance and corporate disclosure, Journal of Accounting Research 18(2): 614-622.

Ioannou, I.; Serafeim, G. 2015. The impact of corporate social responsibility on investment recommendations: analysts' perceptions and shifting institutional logics, Strategic Management Journal 36(7): 1053-1081. http://dx.doi: 10.1002/smj.2268

Ivkovic, Z.; Jegadeesh, N. 2004. The timing and value of forecast and recommendation revisions, Journal of Financial Economics 73(3): 433-463. http://dx.doi:10.1016/j.jfineco.2004.03.002

Jennifer Ho, L. C.; Taylor, M. E. 2007. An empirical analysis of triple bottom-line reporting and its determinants: evidence from the United States and Japan, Journal of International Financial Management \& Accounting 18(2): 123-150. http://dx.doi: 10.1111/j.1467-646X.2007.01010.x

Li, Y.; Richardson, G. D.; Thornton, D. B. 1997. Corporate disclosure of environmental liability information: theory and evidence, Contemporary Accounting Research 14(3):435-474.

Liao, L.; Luo, L.; Tang, Q. 2015. Gender diversity, board independence, environmental committee and greenhouse gas disclosure, British Accounting Review 47(4): 409-424.

http://dx.doi:10.1016/j.bar.2014.01.002 
Luo, L.; Tang, Q. 2014. Does voluntary carbon disclosure reflect underlying carbon performance?, Journal of Contemporary Accounting and Economics 10(3): 191-205. http://dx.doi:10.1016/j.jcae.2014.08.003

Luo, X.; Wangm, H.; Raithel, S.; Zheng, Q. 2015. Corporate social performance, analyst stock recommendations, and firm future returns, Strategic Management Journal 36(1): 123-136. http://dx.doi: 10.1002/smj.2219

Matten, D.; Moon, J. 2008. "Implicit" and "explicit" CSR: a conceptual framework for a comparative understanding of corporate social responsibility, Academy of Management Review 33(2): 404-424. http://dx.doi: 10.5465/AMR.2008.31193458

Meng, X. H.; Zeng, S. X.; Shi, J. J.; Qi, G. Y.; Zhang, Z. B. 2014. The relationship between corporate environmental performance and environmental disclosure: an empirical study in China, Journal of Environmental Management 145(1): 357-367.

http://dx.doi:10.1016/j.jenvman.2014.07.009

Monteiro, S. M. S.; Aibar-Guzmán, B. 2010. Determinants of environmental disclosure in the annual reports of large firms operating in Portugal, Corporate Social Responsibility and Environmental Management 17(4): 185-204. http://dx.doi: 10.1002/csr.197

Neter, J.; Wasserman, W.; Kutner, M. 1983. Applied linear regression models. Illinois: Richard D. Irwin.

Oetzel, J. M.; Bettis, R. A.; Zenner, M. 2001. Country risk measures: how risky are they?, Journal of World Business 36(2): 128-145. http://dx.doi:10.1016/S1090-9516(01)00049-9

Patten, D. M. 2002. The relation between environmental performance and environmental disclosure: a research note, Accounting, Organizations and Society 27(8): 763-773.

http://dx.doi:10.1016/S0361-3682(02)00028-4

Prado-Lorenzo, J. M.; Garcia-Sanchez, I. M. 2010. The role of the board of directors in disseminating relevant information on greenhouse gases, Journal of Business Ethics 97(3): 391-424. http://dx.doi.10.1007/s10551-010-0515-0

Prado-Lorenzo, J. M.; Gallego-Alvarez, I.; Garcia-Sanchez, I. M. 2009. Stakeholder engagement and corporate social responsibility reporting: the ownership structure effect, Corporate Social Responsibility and Environmental Management, 16(2):94-107.

Qiu, Y.; Shaukat, A.; Tharyan, R. 2016. Environmental and social disclosures: link with corporate financial performance, The British Accounting Review 48(1): 102-116.

http://dx.doi:10.1016/j.bar.2014.10.007

Rankin, M.; Windsor, C.; Wahyuni, D. 2011. An investigation of voluntary corporate greenhouse gas emissions reporting in a market governance system: Australian evidence, Accounting, Auditing and Accountability Journal 24(8): 1037-1070. http://dx.doi.org/10.1108/09513571111184751 Reverte, C. 2009. Determinants of corporate social responsibility disclosure ratings by Spanish listed firms, Journal of Business Ethics 88(2): 351-366. http://dx. doi:10.1007/s10551-008-9968-9

Responsible Investment Association Australasia. 2014. Responsible Investment Benchmark Report Australia and New Zealand [online], [cited 1 January, 2015]. Responsible Investment Association Australasia. Available from Internet: http://www.responsibleinvestment.org/wp/content/ uploads/2014/08/RIAABenchmark2013_v3b.pdf

Rodriguez, L. C.; Montiel, I.; Ozuna, T. A. 2014. Conceptualization of how firms engage in corporate responsibility based on country risk, Business and Society 53(5): 625-651.

http://dx.doi: 10.1177/0007650312475123

Said, R.; Omar, N.; Abdullah, W. N. 2013. Empirical investigations on boards, business characteristics, human capital and environmental reporting, Social Responsibility Journal 9(4): 534-553. http://dx.doi.org/10.1108/SRJ-02-2012-0019

Said, R.; Zainuddin, Y. H.; Haron, H. 2009. The relationship between corporate social responsibility disclosure and corporate governance characteristics in Malaysian public listed firms, Social Responsibility Journal 5(2): 212-226. http://dx.doi.org/10.1108/17471110910964496 
Siregar, S. V.; Bachtiar, Y. 2010. Corporate social reporting: empirical evidence from Indonesia Stock Exchange, International Journal of Islamic and Middle Eastern Finance and Management 3(3): 241-252. http://dx.doi.org/10.1108/17538391011072435

Social Investment Organization. 2013. Canadian Socially Responsible INVESTMENT Review 2012 [online], [cited 5 May, 2015]. Social Investment Organization. Available from Internet: http://riacanada.ca/wp-content/uploads/CSRIR-2012-English.pdf

Stock, J. H.; Watson, M. W. 2007. Introduction to econometrics. 2nd ed. Boston: Pearson Addison Wesley.

Tagesson, T.; Blank, V.; Broberg, P.; Collin, S. O. 2009. What explains the extent and content of social and environmental disclosures on corporate websites: a study of social and environmental reporting in Swedish listed corporations, Corporate Social Responsibility and Environmental Management 16(6): 352-364. http://dx.doi: 10.1002/csr.194

Verrecchia, R. 1983. Discretionary disclosure, Journal of Accounting and Economics 5:179-194.

Waddock, S. A.; Graves, S. B. 1997. The corporate social performance financial performance link, Strategic Management Journal 18(4): 303-319.

http://dx.doi:10.1002/(SICI)1097-0266(199704)18:4<303::AID-SMJ869>3.0.CO;2-G

Wang, Z.; Sarkis, J. 2013. Investigating the relationship of sustainable supply chain management with corporate financial performance, International Journal of Productivity and Performance Management 62(8): 871-888. http://dx.doi.org/10.1108/IJPPM-03-2013-0033

Wiseman, J. 1982. An evaluation of environmental disclosures made in corporate annual reports, Accounting, Organizations and Society 7(1): 53-63. http://dx.doi:10.1016/0361-3682(82)90025-3 Wooldridge, J. 2002. Econometric analysis of cross section and panel data. Cambridge, MA: MIT Press.

Grigoris GIANNARAKIS, Dr, is an Adjacent Lecturer in the Department of Business Administration in the Technological Education Institute of Western Macedonia. His scientific field is Corporate Finance. He is an author of more than 12 published papers to different journal including Management Decision, Social Responsibility Journal, Business Strategy and the Environment and many others.

Eleni ZAFEIRIOU, Dr, is an assistant Professor in the Department of Agricultural Development of Democritus University of Thrace. Her scientific field is Applied Economic Statistics, while most of her work is focused on Energy and Agricultural Economics. She is a co-author of three books concerning Methods of Economic Analysis and Statistics. She has been a reviewer of many journals including Economic Modeling, Renewable and Sustainable energy Reviews, Livestock Science and many others. She is a co-author to more than 23 published papers to refereed journals including Forest Policy and Economics, Journal of Business Management and Economics, Business Strategy and the Environment and many others.

Nikolaos SARIANNIDIS, Dr, is an Associate Professor in the Department of Accounting and Finance in the Technological Education Institute of West Macedonia. His scientific field is Business Statistics. $\mathrm{He}$ is a writer of more than 10 books including Econometrics, Statistics and many others. In addition he is a co-author to more than 60 published papers to refereed journals including Business Strategy and the Environment, International Research Journal of Finance and Economics, International Journal of Management and many others.

Kyriaki EFTHALITSIDOU is a post graduate student in the Department of Accounting and Finance in the Technological Education Institute of West Macedonia. Her scientific field is Economics. She is a graduate of the Department of Economics in University of Macedonia. 